\title{
Neural Contributions of the Hypothalamus to Parental Behaviour
}

\author{
Chitose Orikasa
}

check for

updates

Citation: Orikasa, C. Neural Contributions of the Hypothalamus to Parental Behaviour. Int. J. Mol. Sci. 2021, 22, 6998. https://doi.org/ $10.3390 /$ ijms 22136998

Academic Editor: Hirotaka Sakamoto

Received: 1 June 2021

Accepted: 25 June 2021

Published: 29 June 2021

Publisher's Note: MDPI stays neutral with regard to jurisdictional claims in published maps and institutional affiliations.

Copyright: (C) 2021 by the author. Licensee MDPI, Basel, Switzerland. This article is an open access article distributed under the terms and conditions of the Creative Commons Attribution (CC BY) license (https:// creativecommons.org/licenses/by/ $4.0 /$ )
Laboratory for Morphological and Biomolecular Imaging, Nippon Medical School, Sendagi 1, Bunkyo, Tokyo 113-8602, Japan; orikasa@nms.ac.jp

\begin{abstract}
Parental behaviour is a comprehensive set of neural responses to social cues. The neural circuits that govern parental behaviour reside in several putative nuclei in the brain. Melanin concentrating hormone $(\mathrm{MCH})$, a neuromodulator that integrates physiological functions, has been confirmed to be involved in parental behaviour, particularly in crouching behaviour during nursing. Abolishing $\mathrm{MCH}$ neurons in innate $\mathrm{MCH}$ knockout males promotes infanticide in virgin male mice. To understand the mechanism and function of neural networks underlying parental care and aggression against pups, it is essential to understand the basic organisation and function of the involved nuclei. This review presents newly discovered aspects of neural circuits within the hypothalamus that regulate parental behaviours.
\end{abstract}

Keywords: $\mathrm{MCH}$; parental behaviour; nursing; oxytocin; GABA

\section{Introduction}

Maternal behaviour is a distinct sex-related factor in mammalian reproduction. Females exhibit maternal care after parturition, while males who encounter pups engage in infanticide [1-3]. These behaviours depend on sexually dimorphic features of the brain shaped by the effects of gonadal steroid hormones [4-7] and sex chromosomes [8-10]. It is also proposed that epigenetic modifications, i.e., DNA methylation and histone acetylation may regulate gene expression associated with brain sexual differentiation [11]. Brain differentiation between the sexes occurs early in development, during the so-called 'critical' period, leading to differences in neural circuits, endocrine systems and behaviours $[12,13]$ that persist throughout the life of the animal. Gonadal steroids act on the molecular and cellular levels to influence the neural structure and function of the brain. Males are exposed to testicular steroids during this critical neonatal period, resulting in brain masculinisation. In the absence of testicular steroids, the brain is feminised. The differences in sex-dependent reproductive behaviour are assumed to result from these differences in exposure to gonadal steroids during the critical period. Parental care is a reproductive behaviour that can change even in adults in response to alterations in the endocrine milieu or social impetus. In rodents, parturient females display maternal care; virgin females, who are less interested in pups and maternal care, are easily motivated after priming with several exposures to pups [1]. While virgin males sometimes engage in infanticide [3], males that are mating with gestating females exhibit parental behaviour [2,3]. Hormonal circumstances change in adult females, dynamically altering serum oestrogen levels. In female mice, inhibition of oestrogen receptor $\alpha$ in the medial preoptic area results in the absence of maternal behaviours [14]. However, oestrogen replacement therapy in adult male mice has no effect on their parental behaviours (unpublished data). Therefore, the administration of hormones is not sufficient to induce parental behaviour.

In the author's previous study, the social isolation of virgin mice induced parental behaviour in both sexes [15]. In addition, changing the social context has consequences on certain parental behaviours, such as males exhibiting parental nursing behaviour or females ignoring pups. Although sex-dependent behaviours arise from differences in brain differentiation, these behaviours are presumably open to alteration by social stimuli. These 
results suggest that the neuronal pathways involved in parental behaviour retain a high proportion of plasticity, even in adults.

\section{Parental Behaviour in Male Mice}

Male mice who have mated and then cohabitated with gestating and delivering females have been observed to repress attacking pups and to exhibit parental behaviour [2]. We previously observed that parental behaviour in both virgin male and female mice was induced by a very long period of social isolation. Social isolation prompts parental behaviour in both sexes [15]. Studies have reported that social isolation can be a stressful situation in rodents [16-20] and arise as a result of various behavioural changes, i.e., enhanced aggression [19], depression-like behaviour [20] and levels of impulsivity [19]. Moreover, social isolation changes various behaviours, such as aggressive or depressionlike behaviour [21,22]. Aggression using the resident-intruder test [22] revealed that single-housed male mice showed more aggressiveness towards the intruder male mice than the group-housed mice [23]. It is still controversial that isolation stress enhances aggressive behaviour; however, it reduces the attacking of pups. These results suggest that neural circuits in these events differ because of the distinct functional significance in social behaviour. The synaptic machinery of the brain circuits involved in parental behaviour change in response to social conditions. Social isolation in animals and humans is considered as an intensive stressor, which impairs learning. Social isolation is thought to induce changes in social behaviour by inducing neuroanatomical changes that alter the function of the neuroendocrine system. Neuronal plasticity and synaptic remodelling of the nervous system are retained in adulthood under certain conditions, such as isolation stress [16-21,24-26]. In our previous study on MCH-tTA; TetO DTA bigenic mice, +/+ bigenic virgin males with abolished $\mathrm{MCH}$ neurons were more aggressive towards pups presented as well as intruder males than the +/ - controls. Therefore, the possible involvement of neural circuits for aggressiveness towards pups and intruder males is identical to that of responsiveness, including the $\mathrm{MCH}$ neuronal activity. Social isolation elicits presynaptic remodelling in the nucleus accumbens (NAc) neurons, including synaptic plasticity in emotional behavioural responses [27], and changes the synaptic neurotransmission of receptor subtypes in the dorsal raphe nucleus, resulting in altered neuroplastic connectivity regarding social rewards [28].

\section{Evidences of Neuromolecular Regulation of Parental Behaviour}

The medial preoptic area (mPOA) [1-3] and anteroventral periventricular nucleus [29] are critical components of the neural system governing parental behaviour. Candidate regulators of parental behaviour include neuropeptides galanin [30] and oxytocin (OT) [31,32]. Tyrosine hydroxylase is involved in maternal behaviour in females but not in males [29]. Galanin is expressed in the mPOA neurons, which are activated in both sexes by parenting episodes involving pup grooming and retrieval behaviour [3]. OT-secreting neurons in the paraventricular nucleus (PVN) play a crucial role in the onset and maintenance of maternal behaviour in rodents. OT is subjected to nursing and facilitated parental behaviour [32,33], and it then becomes feasible in participating with the auditory cortex in responding to pup calls [31]. In humans, OT release [34] and OT itself improved parenting [35] in terms of the formation of social memory [36,37].

\section{Involvement of MCH Neurons in Parental Care}

Projections from the PVN posterior to the lateral hypothalamic area (LHA) regulate the melanin concentrating hormone $(\mathrm{MCH})$ neurons [38], a neuromodulator that integrates physiological functions [39-55]. Neural projection from OT neuron in PVN to $\mathrm{MCH}$ neuron in LHA [38], which expresses OT receptor [38,50], is involved in mating, parenting and social cognition. Moreover, the $\mathrm{MCH}$ receptor (MCHR) [51] is distributed throughout the area that regulates reward including the NAc [47]. The MCHR distribution correlates 
with oxytocinergic projection and may be involved in the emotional reinforcement of rewards [48].

The MCH, a 19-aminoacid cyclic peptide, was first characterised in salmon pituitary extracts as a circulating factor that mediated colour changes in teleost fishes [56]. $\mathrm{MCH}$ is distributed in the lateral hypothalamus, dorsomedial hypothalamus and zona incerta [57]. In mammals, $\mathrm{MCH}$ neurons play a crucial role as neuromodulators that integrate physiological functions involving energy balance [39-41], sleep [42,49,50], olfaction [43], anxiety [44] reward [45-48], and cognition [48,49]. The ablation of MCHR affects maternal behaviours, especially impaired retrieving pups and increased attacking pups [58].

\section{Effect of Congenital Ablation of MCH on Nursing Behaviour}

Higher expression of the immediate early gene $c$-fos in the $\mathrm{MCH}$ neurons was observed in virgin female and male ddN mice that showed nursing crouching behaviour than in those that ignored their pups after social isolation [59]. To determine the neural rudiment governing nursing behaviour, studies have been conducted in $\mathrm{MCH}$-neuron knockout animals, such as $M C H-t T A$; TetO diphtheria toxin A fragment (DTA) bigenic mice [59] using the tet-off system (Figure 1). MCH neurons are specifically ablated in MCH-tTA; TetO $D T A+/+$ bigenic mice, with the orexin neurons intact. The bigenic MCH-tTA; TetO DTA $+/+$ bigenic female mice had a lower pup survival rate than did MCH-tTA; TetO DTA +/ - bigenic controls. The body weight of MCH-tTA; TetO DTA +/+ bigenic mice was significantly lower in both sexes because of the physiological role of $\mathrm{MCH}$ neurons in food intake [39] and energy metabolism [40,41]. No difference in food intake (Kcal/day) was observed between MCH knockout mice and wild type controls [60]. The locomotor activity of $\mathrm{MCH}$ knockout mice is significantly elevated as compared with controls, resulting in reduced weight gain as a consequence of increased energy expenditure [59]. The virgin $M C H-t T A$; TetO DTA + / + bigenic females display less maternal care in regard to crouching behaviour comparable to that of $M C H-t T A$; TetO DTA +/+ bigenic mothers $\left(X^{2}=11.29\right.$, $\mathrm{df}=1, p=0.001)$, whereas virgin $+/+$ bigenic males exhibit aggressiveness toward their pups (Figure 2). However, no significant difference in retrieving behaviour was observed. Together, these findings indicated that the $\mathrm{MCH}$ neurons play a pivotal role in parental nursing behaviour in mice.

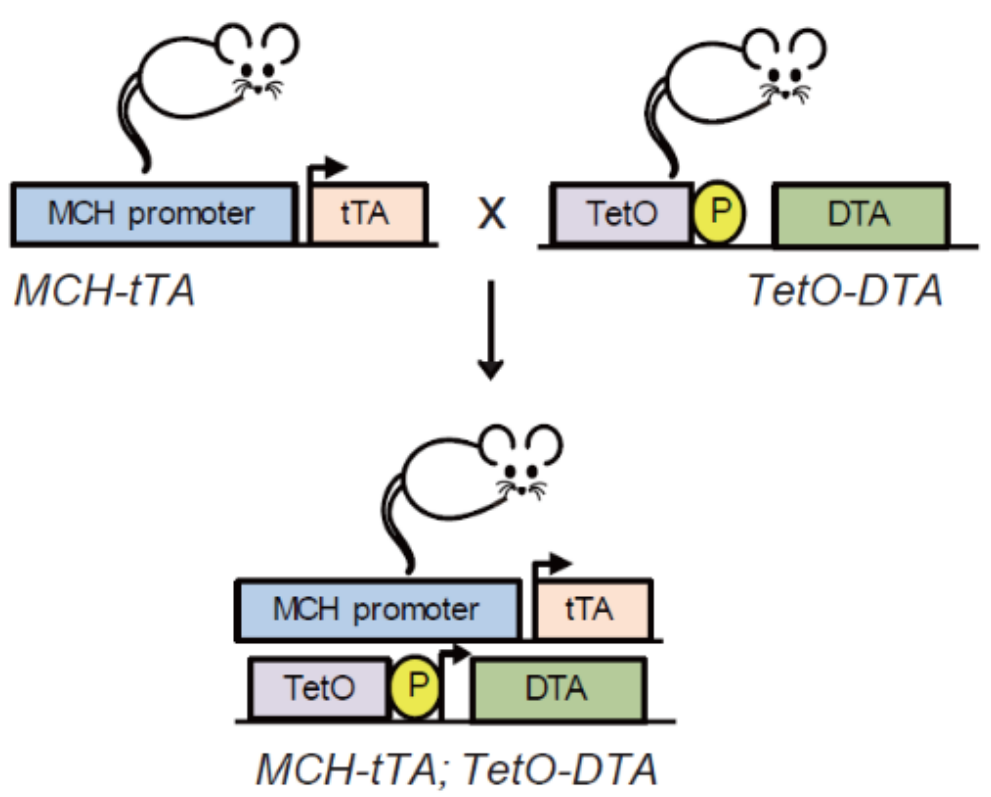

Figure 1. Generation of $\mathrm{MCH}-t \mathrm{TA}$; TetO DTA bigenic mice. Cell-specific stratagem of innate $\mathrm{MCH}$ neurons ablation observed congenitally in the bigenic mice. Tetracycline-controlled gene expression and tTA-induced DTA ablation observed specifically in $\mathrm{MCH}$ neurons (Modified from Tsunematsu et al. [42]). 

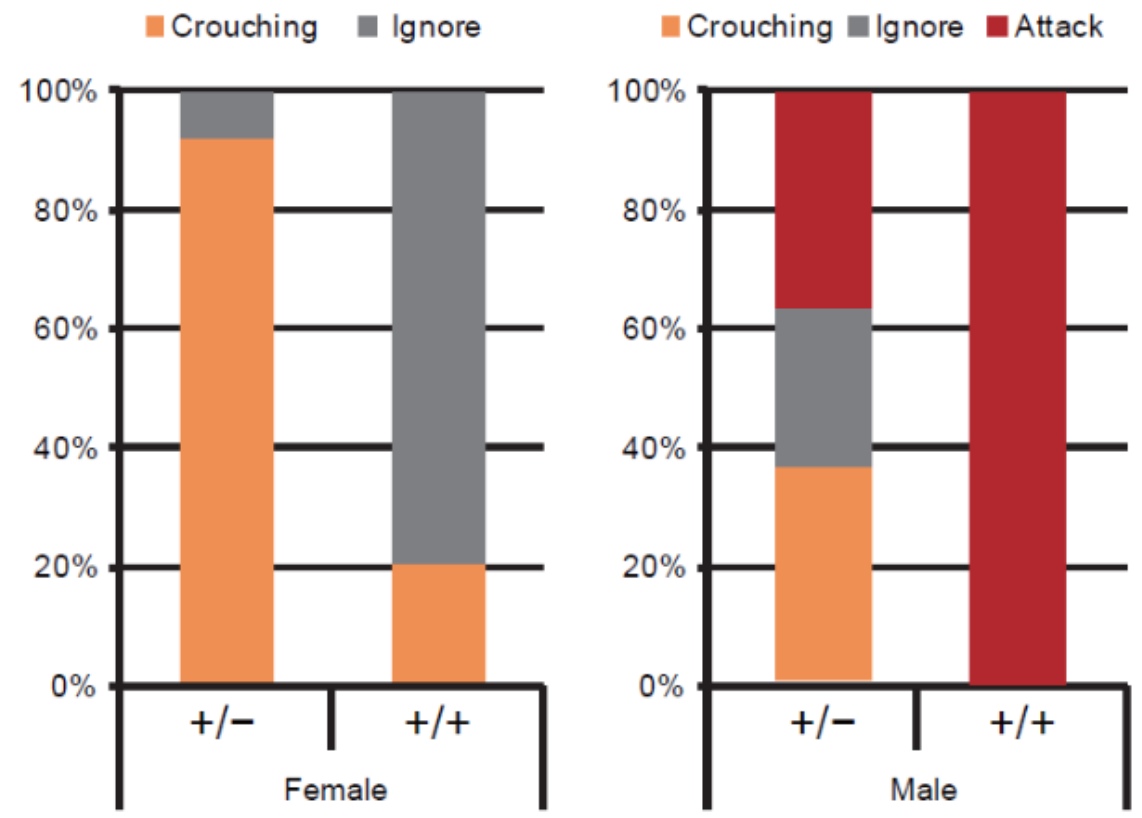

Figure 2. Cell-specific ablation of $\mathrm{MCH}$ neurons impairs nursing behaviour in both virgin female and male mice. Percentage of parental behaviour or attack pups of virgin MCH-tTA; TetO DTA bigenic. +/+ and $+/$ - female (left) and male (right) mice. The ratio of parental behaviour (crouching) in female mice was analysed by Chi-squared test; $\mathrm{X}$-squared $=9.56, \mathrm{df}=1, p=0.002$ (From Kato et al. [59]).

\section{Effect of Optogenetic Stimulation Intensity on Behaviour}

The nursing crouching behaviour was elicited by low-frequency $(473 \mathrm{~nm}, 10 \mathrm{~ms}, 0.5 \mathrm{~Hz}$, $1 \mathrm{~mW}$ ) photo-stimulation through the optic fibres present in both sexes of channelrodopsin 2 (ChR2)-expressing $\mathrm{MCH}$-Cre mice [59]. In contrast, no parental behaviour was observed, in response to applied laser pulsed similar to the condition of rapid eye movement (REM) sleep $(475 \pm 17.5 \mathrm{~nm}, 2.5 \mathrm{~mW}, 10 \mathrm{~ms}, 10 \mathrm{~Hz})$ [42]. The condition of the parental nursing behaviour was a low-frequency stimulation $(473 \mathrm{~nm}, 10 \mathrm{~ms}, 0.5 \mathrm{~Hz}, 1 \mathrm{~mW})$, whereas that of REM sleep induction was a high frequency stimulation $(475 \pm 17.5 \mathrm{~nm}, 2.5 \mathrm{~mW}, 10 \mathrm{~ms}$, $10 \mathrm{~Hz}$ ). ChR2-positive MCH neuron was denoted $c$-fos expression in the condition of animals exhibiting parental nursing behaviour. In animals exhibiting crouching behaviour, about $40 \%$ of the $\mathrm{MCH}$ neurons expressed ChR2, and $10 \%$ of the ChR2-positive $\mathrm{MCH}$ neurons expressed c-fos [59]. A previous study of the ventromedial hypothalamus (VMH) showed that mounting and attacking intruder males were elicited by different intensities of the oestrogen receptor 1 (Esr1) in the ventromedial nucleus [61,62]. Optogenetic induction of attack requires the presence of more Ers1 cells containing ChR2 than does the induction of mounting behaviour. Therefore, optogenetic stimulation might coordinate the threshold activity more robustly and coincide with tuned cells, inducing either attack or opposing other behaviours. The number of Esr1 cells expressing ChR2 and c-fos was much higher in case of induction of attack than that in case of mounting behaviour. These findings suggest that each behaviour is dependent on the frequency and intensity of photo-stimulation. Therefore, the type of behaviour elicited depends on the responsiveness of the neurons regulating the particular behaviour. Sensory cues, required for activating distinct neuronal populations in the same nucleus with different thresholds, are responsible for determining specific behaviours. The strength of the optogenetic photo-stimulation corresponds to signals from the accumulation of olfactory, auditory, haptic, visual and environmental cues.

Some of the neurons in the VMH, involved in mating, attacking or both are responsive to appropriate stimulation in the nucleus. Low-intensity signals induce mating, while highintensity signals elicit attack behaviour [62]. We ask the question: Why do the functional differences in the same nucleus lead to behaviour differences, and how do neurons in the hypothalamus convey sensory information to induce inherent behaviours? The $\mathrm{MCH}$ 
neuronal state for behaviour is variably induced by photo-stimulation: Low stimulation elicits nursing, and high stimulation elicits REM sleep. The neural circuit responsible for this MCH-induced behaviour could communicate with other brain areas to integrate each behaviour. The extraordinary event of the behaviour must be induced by different reactivities of the responsible neurons.

\section{MCH Neural Relay in PVN Oxytocin Neurons Is Involved in Nursing Behaviour}

Further evidence shows that MCH neurons are regulated by OT neurons in PVN that project anatomically posterior to LHA [38]. OT, a neurotransmitter synthesised in both the PVN and supraoptic nuclei of the hypothalamus [63], regulates peripheral reproductiverelated functions and central actions in the brain. OT secretion from the posterior pituitary gland induces uterine contractions during parturition and also acts on the muscle in the mammary gland trabeculae to induce milk ejection during lactation [63]. Oxytocinergic neurons are involved in a variety of central nervous system functions. Centrally and peripherally secreted OT acts through the OT receptor. This receptor is distributed in the ventral tegmental area (VTA) and NAc and is involved in feeding, sexual behaviour and reward properties of social interactions and the formation of social bonds. OT has been shown to facilitate the onset of maternal behaviour in rodents [31,32]. The possible mechanism responsible for parental nursing behaviour is involved in the neural relay for the LHA-PVN within the hypothalamus. Studies have shown that the periaqueductal grey (PAG) in the midbrain is implicated in reproductive behaviour such as the females' lordosis behaviour and the maternal arched back crouching behaviour, whereas no effects were recorded in the pup grooming behaviour [64-66].

Alternatively, the stimulation of the projection to the PAG from the galanin neurons results in pup grooming, albite with no effect on crouching in both sexes [30]. Maternal behaviour could be regulated by the LHA-MCH neuronal input to the PAG. GABAergic neurons in the LHA-to-PAG projection precipitate in predatory hunting in mice [66]. Whereas, the role of the $\mathrm{MCH}$ receptor in the PAG is yet to be determined. However, the method whereby the neural circuit for these diverse parenting behaviours govern each of the behavioural contents is still controversial.

\section{OT Enhances the Neural Circuits of Rewarding from Pups}

Previous studies have identified the $\mathrm{mPOA}$ as a critical region in the regulation of parental behaviour [1-3,30,67-70]. OT neurons act on mPOA, VTA and NAc to prompt parental behaviour. OT neurons in PVN receive the projection from the LHA [59]. In our previous study, MCH-tTA; TetO DTA bigenic $(+/+)$ female mice with the complete innate ablation of $\mathrm{MCH}$ neurons displayed less attention towards pups and less maternal care than MCH-tTA; TetO DTA +/ - bigenic controls, which was similar to MCH-tTA; TetO DTA $+/+$ bigenic mothers, that display significantly lowered crouching than the $+/-$ controls. Moreover, the virgin $+/+$ bigenic females showed significantly lowered crouching than $\mathrm{MCH}-t \mathrm{TA}$; TetO DTA + / - bigenic controls. MCH neurons are ablated partially using Cre recombinase-dependent DTA, which abolishes approximately 73\% of $\mathrm{MCH}$ neurons in virgin females. Virgin females with partially ablated $\mathrm{MCH}$ neurons exhibit crouching behaviour for less time than green florescent protein controls. The MCHR expression is necessary to the reward circuitry of the NAc as is the anatomic integrity of the oxytocinergic projection of the mesolimbic system; these findings indicate a possible alliance between these factors in the emotional reinforcement of rewards for parenting. The MCHR is expressed in the olfactory regions, neocortex, hippocampus, NAc, amygdala, ventromedial hypothalamic nucleus and locus coeruleus. OT receptor expression [71], coupled with MCHR in the NAc has a synergistic effect on inherent rewarding, contributing to the execution of parental behaviour [72]. Therefore, $\mathrm{MCH}$ neural networks along with OT signalling in reward circuitry facilitate pup survival.

Maternal rewards system may contribute to maternal nursing systems. Relationships between maternal depression and OT levels were demonstrated previously [73]. MCH- 
LHA projects closely to OT-PVN, which is the stimulation that induces parental behaviour along with increasing plasma OT levels [59]. The recurrent process between the PVN projection to LHA and the LHA projection to PVN are assumed to be tuning properties for continuous parenting crouching behaviour. Almost all $\mathrm{MCH}$ neurons expressed OT receptor mRNA; however, OT neurons faintly expressed the $\mathrm{MCH}$ receptor $[38,50]$.

\section{Social Isolation Modifies GABAergic Transmission}

Extended periods of social isolation can affect parental behaviour by inducing neuroanatomical changes. The expression of the immediate early gene $c$-fos in the $\mathrm{MCH}$ neurons increased during parental nursing behaviour of mice after social isolation [59]. $\mathrm{MCH}$ neurons in the LHA contain and release $\gamma$-aminobutyric acid (GABA) $[59,74]$ as well as express GABA-synthesising enzymes GAD65 and GAD67 [59,75,76]. MCH neurons also contain and release glutamate in the lateral septum $[77,78]$. In the amygdala neural circuits, GABAergic and glutamatergic neurons in the VTA specifically tune each rewarding and aversive motivational predicaments [79]. $\mathrm{MPOA}$, which is indicative of GABAergic neurotransmission, governs parental behaviour, whereas glutamatergic neurons in the same nucleus are associated with anxiety-like behaviour [80]. Glutamatergic neurons in the mPOA regulate anxiety-like behaviour, while GABAergic neurons contribute to anxiolytic effects, i.e., parental behaviour, indicating that the mPOA in the same nucleus plays a crucial role in reconciliation of opposite behaviours. Moreover, the mPOA projections to the neurons in midbrain reward circuits may prompt parental behavior with accommodation for dopamine release [80]. Therefore, GABAergic and glutamatergic neurons play a prominent role in opposing effects on the social behaviour. These results suggest that the same nucleus governs opposite positive or negative behaviours by discriminating the neurotransmission of the nucleus. Social isolation, which prompts parental behaviour for several resting weeks, could change the statement of the brain neurotransmission. In fact, conditions, such as accrues to excitatory neurotransmission of GABA neurons result in a profound depolarising shift in magnocellular neurosecretory cells that secrete OT in the PVN [81]. Our previous study has shown that $\mathrm{MCH}$ fibre expressing enhanced yellow fluorescent protein projected close proximity to the OT neuron in the PVN. The $\mathrm{MCH}$ neuron was revealed to express GABA, which innervates as a neurotransmitter and forms synapses with OT neurons [59]. Moreover, GABA agonist musicimol injected into the $\mathrm{PVN}$ increases $c-f o s$ in the OT neurons. More $c$-fos expressing OT neurons were observed in the socially isolated female and male mice than the co-habituated female and male mice [59], indicating that the $\mathrm{MCH}$ neuron could regulate excitatory OT neurons in the PVN. Although GABA principally functions as an inhibitory neurotransmitter in the brain, excitatory GABAergic activity is identified in $\mathrm{MCH}$ neurons during development [82]. In mature neurons, but the excitatory action of GABA under stress conditions has been elucidated [83-86]. Social isolation might be presumed to be a validated stressor and to elicit changes in the synaptic organisation action in the rodent brain $[16,28]$.

Therefore, social isolation stress may change the mode of GABAergic excitation. The projection from LHA to PVN under social, reward-context associations are responsible for the LHA-PVN-evoked OT releases implicated in parenting augmentation. Therefore, social isolation may change the mechanisms underlying the modality of GABAergic excitation. Abolishing $\mathrm{MCH}$ neurons may induce the superiority of glutamatergic circuit, thereby, stimulating broad area commitment to infanticide in the brain. Moreover, the impairment of OT neurons showed acceleration aggression. The balance between GABA and glutamate utilisation in the $\mathrm{MCH}$ neurons in some aspects of parental and opposing behaviours remains to be elucidated.

\section{Aggressive Behaviour towards Pups}

Pheromonal signals are received by neurons in the vomeronasal organ (VNO) [87] and the main olfactory epithelium within the nasal cavity [88]. In rodents, olfaction is known to be important for the identification of conspecifics and sex differentiation. The excision of the 
olfactory bulb results in defects in aggressive behaviour, indicating that olfactory perception is involved in dictating aggressiveness. A body of evidence implicates neural networks in the governing of aggressive behaviour, including a social behaviour circuit involving the mPOA, medial amygdala (MeA), bed nucleus of the stria terminalis (BNST) [89], lateral septum, anterior hypothalamus, VMH and PAG [65]. Social signals detected by the olfactory bulb are subsequently transmitted to specific brain regions: MeA and then to the VMH or BNST [90]. The VMH is downstream of the MeA, which in turn disinhibits the VMHvl glutamatergic neuron induction of aggressive behaviour; for example, this circuitry guides the behaviour in which male mice attack male intruders but not females [91,92]. Distinguishing between females and males is also accomplished through the detection of semiochemicals, some of which are major urinary proteins $[93,94]$. These chemicals are detected by sensory neurons in the VNO in a sex-dependent manner [95-97]. For example, during infanticide by virgin male mice, pheromonal signals from pups via the VNO are sent to the accessory olfactory bulb, then to the MeA and relayed to the anterior hypothalamic area/VMH and BNST. The VNO neurons presumably are involved in the detection of pheromonal signals related to parental care [3]. Knockout of cation channel subfamily C member 2 (Trpc2) in male mice causes impaired VNO-input signalling, resulting in reduced attacking of pups, indicating that VNO signalling elicits the attacking of pups [98-100]. Our previous study reports that $\operatorname{Trpc} 2 \mathrm{KO}$ mice spent more time licking the pups and crouching after social isolation. However, retrieval behaviour increased only in response to social isolation and was not affected by Trpc2 $\mathrm{KO}$. These results indicate that not all the social signals are transmitted by the VNO [101].

The MCH-tTA; TetO DTA +/+ bigenic virgin males with ablated $\mathrm{MCH}$ neurons were more aggressive toward the pups. In the resident-intruder test, the $M C H-t T A$; TetO DTA $+/+$ bigenic virgin mice, exhibited more male-male aggression than did MCH-tTA; TetO $D T A+/-$ bigenic controls [59]. Ablation of MCH neurons also leads MCH-tTA; TetO DTA +/+ bigenic male mice to exhibit more aggressiveness against other male mice and pups, suggesting that $\mathrm{MCH}$ neurons disinhibit the olfactory circuit and sensory integration from the olfactory bulb. This result is similar to that observed with neural circuit modulation that results in male attack on pups and intermale aggressive behaviour [102]. The MeA is evidenced as an inhibitor of maternal behaviour [103-107]. Moreover, MCHR in the MeA is assumed to be implicated in maternal aggression towards intruder male [107]. The VNO and main olfactory bulb may be substantially involved in male-male aggressive behaviour prompted by pheromones [100] and play decisive roles in conferring infanticide in mice. The MCH-tTA; TetO DTA + / + bigenic virgin mice were able to mate because of their ability to discriminate sex due to their preserved VNO function. Neural circuits for attacking pups may be involved in relaying from MCH neurons in the LHA (MCH-LHA) to OT neurons in the PVN (OT-PVN) in rodents [59].

The ablation of $\mathrm{MCH}$ neuron excitability to PVN may prevent the induction of OT secretion. In contrast, $M C H-t T A ; T e t O D T A+/+$ bigenic female mice ignore the pups, indicating that the effect of abolishing $\mathrm{MCH}$ neurons differed in some degree between females and males. OT transmits signals involved in social interactions, such as parental and pair bonding; abolishing OT facilitates aggressive behaviour [108]. Presumably, OT acts on the mPOA, which induces parental behaviour in rats [109,110].

Another proposed mechanism is effects on OT, which acts to regulate the salience of external social cue rather than affiliative behaviours [111-113], which is a critical role of OT in the event of the discriminate mode of an emotional action in a conspecific [114].

\section{Parental Licking Behaviour}

Optogenetically-evoked crouching behaviour requires around $10 \%$ of the ChR2expressing and $\mathrm{MCH}$ cells that express $c$-fos. The photo-stimulation of $\mathrm{ChR} 2 \mathrm{MCH}$ neurons significantly increased crouching behaviour, but did not affect licking behaviour [59]. Therefore, the relative contribution of $\mathrm{MCH}$ neurons to licking behaviour may be minimal. 
Mice contact pups at first and pup-licking is assumed to be dictated by emotive excitation or apprehension $[115,116]$.

Optogenetic stimulation of galanin neurons in the mPOA induces retrieving and pup grooming rather decreasing attacking pups [30] and had no effect on other parental behaviours. Genetical ablation of galanin neurons in the mPOA induces pup attacking in virgin females but not in mating-experienced females and males. Therefore, the brain centre for pup retrieving and grooming behaviour is in the $\mathrm{mPOA}$, and galanin is one of the molecules involved in parenting pup grooming. Pup grooming behaviour is also affected by GABAergic neurons in the posterodorsal (MeApd) in females [78]. The effect of photo-stimulation on retrieving pups and crouching is less than that on pup grooming. Higher GABAergic neuron activity in the MeApd induces the attacking of pups, while low activity of these neurons prompts parenting in male mice. Opposing behaviours, such as parenting and aggression, are centred in different regions of the brain. For example, MeApd facilitates parenting behaviour, while aggression is colinear with the quantitative responses of GABAergic neurons in the brain.

\section{Conclusions}

Parental behaviour is composed of sequential behaviour events induced by an associated nucleus for each event that is stimulated by a social cue. In this chapter, I proposed that the key brain regions and molecules involved in regulating parental behaviour reside in the POA, the focus of much research on this topic. Genetic ablation of $\mathrm{MCH}$ neurons in transgenic, $M C H-t T A ;$ TetO DTA +/+ mice results in impaired nursing parental behaviour. Virgin $M C H-t T A$; TetO DTA +/+ bigenic males engaged in infanticide toward the pups, while females ignored pups. A neural circuit from the LHA-MCH to PVN-OT was revealed in this study, and $\mathrm{MCH}$ reward neural circuitry, together with OT signalling, is a requisite for parental behaviours that promote pup survival.

Funding: This work was funded, in part, by grants-in-aid for scientific research from the Japanese Ministry of Education, Science, Sports and Culture [19K12738] (C.O.).

Institutional Review Board Statement: Not applicable.

Informed Consent Statement: Not applicable.

Data Availability Statement: Not applicable.

Acknowledgments: The author thanks A. Inutsuka, Y. Kato, S. Minami, T. Onaka, A. Yamanaka and H. Katsumata for their helpful advice and technical assistance.

Conflicts of Interest: The author declares no conflict of interest.

\section{References}

1. Numan, M. The Parental Behavior: Mechanisms, Development, and Evolution; Oxford University Press: Oxford, UK, 2020.

2. Tachikawa, K.S.; Yoshihara, Y.; Kuroda, K.O. Behavioral transition from attack to parenting in male Mice: A crucial role of the vomeronasal system. J. Neurosci. 2013, 33, 5120-5126. [CrossRef]

3. Wu, Z.; Autry, A.E.; Bergan, J.F.; Watabe-Uchida, M.; Dulac, C.G. Galanin neurons in the medial preoptic area govern parental behaviour. Nature 2014, 509, 325-330. [CrossRef]

4. Marrocco, J.; McEwen, B.S. Sex in the brain: Hormones and sex differences. Dialogues Clin. Neurosci. 2016, 18, 373-383. [PubMed]

5. Ubuka, T.; Trudeau, V.L.; Parhar, I. Editorial: Steroids and the Brain. Front. Endocrinol. 2020, 11, 366. [CrossRef]

6. Blakemore, J.; Naftolin, F. Aromatase: Contributions to Physiology and Disease in Women and Men. Physiology 2016, 31, 258-269. [CrossRef]

7. McEwen, B.S. Hormones and behavior and the integration of brain-body science. Horm. Behav. 2020, 119, 104619. [CrossRef]

8. Arnold, A.P. A general theory of sexual differentiation. J. Neurosci. Res. 2017, 95, 291-300. [CrossRef]

9. Bakker, J. The Sexual Differentiation of the Human Brain: Role of Sex Hormones Versus Sex Chromosomes. In Neuroendocrine Regulation of Behavior; Springer: Cham, Switzerland, 2018; Volume 43, pp. 45-67.

10. McCarthy, M.M.; Wright, C.L. Convergence of Sex Differences and the Neuroimmune System in Autism Spectrum Disorder. Biol. Psychiatry 2017, 81, 402-410. [CrossRef]

11. Forger, N.G. Epigenetic mechanisms in sexual differentiation of the brain and behaviour. Philos. Trans. R. Soc. B Biol. Sci. 2016, 371, 20150114. [CrossRef] 
12. Döhler, K.D.; Coquelin, A.; Davis, F.; Hines, M.; Shryne, J.E.; Gorski, R.A. Differentiation of the sexually dimorphic nucleus in the preoptic area of the rat brain is determined by the perinatal hormone environment. Neurosci. Lett. 1982, 33, 295-298. [CrossRef]

13. Mhaouty-Kodja, S.; Naulé, L.; Capela, D. Sexual Behavior: From Hormonal Regulation to Endocrine Disruption. Neuroendocrinology 2018, 107, 400-416. [CrossRef]

14. Ribeiro, A.C.; Musatov, S.; Shteyler, A.; Simanduyev, S.; Arrieta-Cruz, I.; Ogawa, S.; Pfaff, D.W. siRNA silencing of estrogen receptor- $\alpha$ expression specifically in medial preoptic area neurons abolishes maternal care in female mice. Proc. Natl. Acad. Sci. USA 2012, 109, 16324-16329. [CrossRef] [PubMed]

15. Orikasa, C.; Nagaoka, K.; Katsumata, H.; Sato, M.; Kondo, Y.; Minami, S.; Sakuma, Y. Social isolation prompts maternal behavior in sexually naïve male ddN mice. Physiol. Behav. 2015, 151, 9-15. [CrossRef]

16. Mumtaz, F.; Khan, M.I.; Zubair, M.; Dehpour, A.R. Neurobiology and consequences of social isolation stress in animal model-A comprehensive review. Biomed. Pharm. 2018, 105, 1205-1222. [CrossRef]

17. Buwalda, B.; Geerdink, M.; Vidal, J.; Koolhaas, J.M. Social behavior and social stress in adolescence: A focus on animal models. Neurosci. Biobehav. Rev. 2011, 35, 1713-1721. [CrossRef]

18. Farbstein, D.; Hollander, N.; Peled, O.; Apter, A.; Fennig, S.; Haberman, Y.; Gitman, H.; Yaniv, I.; Shkalim, V.; Pick, C.G.; et al. Social isolation in mice: Behavior, immunity, and tumor growth. Stress 2021, 24, 229-238. [CrossRef] [PubMed]

19. Takeda, A.; Tamano, H.; Kan, F.; Hanajima, T.; Yamada, K.; Oku, N. Enhancement of social isolation-induced aggressive behavior of young mice by zinc deficiency. Life Sci. 2008, 82, 909-914. [CrossRef]

20. O'Keefe, L.M.; Doran, S.J.; Mwilambwe-Tshilobo, L.; Conti, L.H.; Venna, V.R.; McCullough, L.D. Social isolation after stroke leads to depressive-like behavior and decreased BDNF levels in mice. Behav. Brain Res. 2014, 260, 162-170. [CrossRef]

21. Koike, H.; Ibi, D.; Mizoguchi, H.; Nagai, T.; Nitta, A.; Takuma, K.; Nabeshima, T.; Yoneda, Y.; Yamada, K. Behavioral abnormality and pharmacologic response in social isolation reared mice. Behav. Brain Res. 2009, 202, 114-121. [CrossRef]

22. Kozhemyakina, R.V.; Shikhevich, S.G.; Konoshenko, M.Y.; Gulevich, R.G. Adolescent oxytocin treatment affects resident behavior in aggressive but not tame adult rats. Physiol. Behav. 2020, 224, 113046. [CrossRef]

23. Tan, O.; Musullulu, H.; Raymond, J.S.; Wilson, B.; Langguth, M.; Bowen, M.T. Oxytocin and vasopressin inhibit hyper-aggressive behaviour in socially isolated mice. Neuropharmacology. 2019, 156, 107573. [CrossRef] [PubMed]

24. Stevenson, J.R.; McMahon, E.K.; Boner, W.; Haussmann, M.F. Oxytocin administration prevents cellular aging caused by social isolation. Psychoneuroendocrinology 2019, 103, 52-60. [CrossRef]

25. Ferdman, N.; Murmu, R.P.; Bock, J.; Braun, K.; Leshem, M. Weaning age, social isolation, and gender, interact to determine adult explorative and social behavior, and dendritic and spine morphology in prefrontal cortex of rats. Behav. Brain Res. 2007, 180, 174-182. [CrossRef]

26. Du Preez, A.; Onorato, D.; Eiben, I.; Musaelyan, K.; Egeland, M.; Zunszain, P.A.; Fernandes, C.; Thuret, S.; Pariante, C.M. Chronic stress followed by social isolation promotes depressive-like behaviour, alters microglial and astrocyte biology and reduces hippocampal neurogenesis in male mice. Brain Behav. Immun. 2021, 91, 24-47. [CrossRef] [PubMed]

27. Deguchi, Y.; Harada, M.; Shinohara, R.; Lazarus, M.; Cherasse, Y.; Urade, Y.; Yamada, D.; Sekiguchi, M.; Watanabe, D.; Furuyashiki, T.; et al. mDia and ROCK Mediate Actin-Dependent Presynaptic Remodeling Regulating Synaptic Efficacy and Anxiety. Cell Rep. 2016, 17, 2405-2417. [CrossRef]

28. Matthews, G.A.; Edward, H.; Nieh, E.H.; Weele, C.M.V.; Halbert, S.A.; Pradhan, R.V.; Yosafat, A.S.; Glober, G.F.; Izadmehr, E.M.; Thomas, R.E.; et al. Dorsal Raphe Dopamine Neurons Represent the Experience of Social Isolation. Cell 2016, 164, 617-631. [CrossRef]

29. Scott, N.; Prigge, M.; Yizhar, O.; Kimchi, T. A sexually dimorphic hypothalamic circuit controls maternal care and oxytocin secretion. Nature 2015, 525, 519-522. [CrossRef] [PubMed]

30. Kohl, J.; Babayan, B.M.; Rubinstein, N.D.; Autry, A.E.; Marin-Rodriguez, B.; Kapoor, V.; Miyamishi, K.; Zweifel, L.S.; Luo, L.; Uchida, N.; et al. Functional circuit architecture underlying parental behaviour. Nature 2018, 556, 326-331. [CrossRef] [PubMed]

31. Marlin, B.J.; Mitre, M.; D’amour, J.A.; Chao, M.V.; Froemke, R.C. Oxytocin enables maternal behaviour by balancing cortical inhibition. Nature 2015, 520, 499-504. [CrossRef] [PubMed]

32. Watarai, A.; Tsutaki, S.; Nishimori, K.; Okuyama, T.; Mogi, K.; Kikusui, T. The blockade of oxytocin receptors in the paraventricular thalamus reduces maternal crouching behavior over pups in lactating mice. Neurosci. Lett. 2020, 720, 134761. [CrossRef] [PubMed]

33. Yoshihar, C.; Numan, M.; Kuroda, K.O. Oxytocin and Parental Behaviors. Curr. Top. Behav. Neurosci. 2018, 35, 119-153.

34. Rassovsky, Y.; Harwood, A.; Zagoory-Sharon, O.; Feldman, R. Martial arts increase oxytocin production. Sci. Rep. 2019, 9, 12980. [CrossRef]

35. Tse, W.S.; Siu, A.F.Y.; Zhang, Q.; Chan, H.Y.E. Maternal oxytocin responsiveness improves specificity of positive social memory recall. Psychoneuroendocrinology 2018, 98, 148-152. [CrossRef]

36. Bartz, J.A.; Zaki, J.; Ochsner, K.N.; Bolger, N.; Kolevzon, A.; Ludwig, N.; Lydon, J.E. Effects of oxytocin on recollections of maternal care and closeness. Proc. Natl. Acad. Sci. USA 2010, 107, 21371-21375. [CrossRef]

37. Brill-Maoz, N.; Maroun, M. Extinction of fear is facilitated by social presence: Synergism with prefrontal oxytocin. Psychoneuroendocrinology 2016, 66, 75-81. [CrossRef] [PubMed]

38. Yao, Y.; Fu, L.Y.; Zhang, X.; van den Pol, A.N. Vasopressin and oxytocin excite MCH neurons, but not other lateral hypothalamic GABA neurons. Am. J. Physiol. Regul. Integr. Comp. Physiol. 2012, 302, R815-R824. [CrossRef] 
39. Qu, D.; Ludwig, D.S.; Gammeltoft, S.; Piper, M.; Pelleymounter, M.A.; Cullen, M.J.; Mathes, W.F.; Przypek, R.; Kanarek, R.; Maratos-Flier, E. A role for melanin-concentrating hormone in the central regulation of feeding behaviour. Nature 1996, 380, 243-247. [CrossRef] [PubMed]

40. Shimada, M.; Tritos, N.A.; Lowell, B.B.; Flier, J.S.; Maratos-Flier, E. Mice lacking melanin-concentrating hormone are hypophagic and lean. Nature 1998, 396, 670-674. [CrossRef]

41. Marsh, D.J.; Weingarth, D.T.; Novi, D.E.; Chen, H.Y.; Trumbauer, M.E.; Chen, A.S.; Guan, X.M.; Jiang, M.M.; Feng, Y.; Camacho, R.E.; et al. Melanin-concentrating hormone 1 receptor-deficient mice are social isolation stress rodent lean, hyperactive, and hyperphagic and have altered metabolism. Proc. Natl. Acad. Sci. USA 2002, 99, 3240-3245. [CrossRef] [PubMed]

42. Tsunematsu, T.; Ueno, T.; Tabuchi, S.; Inutsuka, A.; Tanaka, K.F.; Hasuwa, H.; Kilduff, T.S.; Terao, A.; Yamanaka, A. Optogenetic manipulation of activity and temporally controlled cell-specific ablation reveal a role for $\mathrm{MCH}$ meurons in sleep/wake regulation. J. Neurosci. 2014, 34, 6896-6909. [CrossRef]

43. Alhassen, L.; Phan, A.; Alhassen, W.; Nguyen, P.; Lo, A.; Shaharuddin, H.; Sanathara, N.; Civelli, O.; Alachkar, A. The role of Olfaction in MCH-regulated spontaneous maternal responses. Brain Res. 2019, 1719, 71-76. [CrossRef]

44. Concetti, C.; Bracey, E.F.; Peleg-Raibstein, D.; Burdakov, D. Control of fear extinction by hypothalamic melanin-concentrating hormone-expressing neurons. Proc. Natl. Acad. Sci. USA 2020, 117, 22514-22521. [CrossRef]

45. García-Fuster, M.J.; Parks, G.S.; Clinton, S.M.; Watson, S.J.; Akil, H.; Civelli, O. The melanin-concentrating hormone (MCH) system in an animal model of depression-like behavior. Eur. Neuropsychopharmacol. 2012, 22, 607-613. [CrossRef]

46. Blouin, A.M.; Fried, I.; Wilson, C.L.; Staba, R.J.; Behnke, E.J.; Lam, H.A.; Maidment, N.T.; Karlsson, K.Æ.; Lapierre, J.L.; Siegel, J.M. Human hypocretin and melanin-concentrating hormone levels are linked to emotion and social interaction. Nat. Commun. 2013, 4, 1547. [CrossRef]

47. Roy, M.; David, N.; Cueva, M.; Giorgetti, M. A study of the involvement of melanin-concentrating hormone receptor 1 (MCHR1) in murine models of depression. Biol. Psychiatry. 2007, 61, 174-180. [CrossRef]

48. Sherwood, A.; Wosiski-Kuhn, M.; Nguyen, T.; Holland, P.C.; Lakaye, B.; Adamantidis, A.; Johnson, A.W. The role of melaninconcentrating hormone in conditioned reward learning. Eur. J. Neurosci. 2012, 36, 3126-3133. [CrossRef]

49. Izawa, S.; Chowdhury, S.; Miyazaki, T.; Mukai, Y.; Ono, D.; Inoue, R.; Ohmura, Y.; Mizoguchi, H.; Kimura, K.; Yoshioka, M.; et al. REM sleep-active MCH neurons are involved in forgetting hippocampus-dependent memories. Science 2019, 365, 1308-1313. [CrossRef]

50. Komagata, N.; Latifi, B.; Rusterholz, T.; Bassetti, C.L.A.; Adamantidis, A.; Schmidt, M.H. Dynamic REM Sleep Modulation by Ambient Temperature and the Critical Role of the Melanin-Concentrating Hormone System. Curr. Biol. 2019, 29, 1976-1987.e4. [CrossRef]

51. Saito, Y.; Cheng, M.; Leslie, F.M.; Civelli, O. Expression of the melanin-concentrating hormone (MCH) receptor mRNA in the rat brain. J. Comp. Neurol. 2001, 435, 26-40. [CrossRef] [PubMed]

52. Jang, J.H.; Park, J.Y.; Oh, J.Y.; Bae, S.J.; Jang, H.; Jeon, S.; Kim, J.; Park, H.J. Novel analgesic effects of melanin-concentrating hormone on persistent neuropathic and inflammatory pain in mice. Sci. Rep. 2018, 8, 707. [CrossRef]

53. Teixeira, P.D.S.; Wasinski, F.; Lima, L.B.; Frazão, R.; Bittencourt, J.C.; Donato, J., Jr. Regulation and neurochemical identity of melanin-concentrating hormone neurones in the preoptic area of lactating mice. J. Neuroendocrinol. 2020, 32, e12818. [CrossRef] [PubMed]

54. Kawata, Y.; Okuda, S.; Hotta, N.; Igawa, H.; Takahashi, M.; Ikoma, M.; Kasai, S.; Ando, A.; Satomi, Y.; Nishida, M.; et al. A novel and selective melanin-concentrating hormone receptor 1 antagonist ameliorates obesity and hepatic steatosis in diet-induced obese rodent models. Eur. J. Pharmacol. 2017, 796, 45-53. [CrossRef] [PubMed]

55. Sanathara, N.M.; Garau, C.; Alachkar, A.; Wang, L.; Wang, Z.; Nishimori, K.; Xu, X.; Civelli, O. Melanin concentrating hormone modulates oxytocin-mediated marble burying. Neuropharmacology 2018, 128, 22-32. [CrossRef] [PubMed]

56. Kawauchi, H.; Kawazoe, I.; Tsubokawa, M.; Kishida, M.; Baker, B.I. Characterization of melanin-concentrating hormone in chum salmon pituitaries. Nature 1983, 305, 321-323. [CrossRef]

57. Bittencourt, J.C.; Presse, F.; Arias, C.; Peto, C.; Vaughan, J.; Nahon, J.L.; Vale, W.; Sawchenko, P.E. The melanin-concentrating hormone system of the rat brain: An immuno- and hybridization histochemical characterization. J. Comp. Neurol. 1992, 319, 218-245. [CrossRef]

58. Alachkar, A.; Alhassen, L.; Wang, Z.; Wang, L.; Onouye, K.; Sanathara, N.; Civelli, O. Inactivation of the melanin concentrating hormone system impairs maternal behavior. Eur. Neuropsychopharmacol. 2016, 26, 1826-1835. [CrossRef]

59. Kato, Y.; Katsumata, H.; Inutsuka, A.; Yamanaka, A.; Onaka, T.; Minami, S.; Orikasa, C. Involvement of MCH-oxytocin neural relay within the hypothalamus in murine nursing behavior. Sci. Rep. 2021, 11, 3348. [CrossRef]

60. Kokkotou, E.; Jeon, J.Y.; Wang, X.; Marino, F.E.; Carlson, M.; Trombly, D.J.; Maratos-Flier, E. Mice with MCH ablation resist diet-induced obesity through strain-specific mechanisms. Am. J. Physiol. Regul. Integr. Comp. Physiol. 2005, 289, R117-R124. [CrossRef]

61. Remedios, R.; Kennedy, A.; Zelikowsky, M.; Grewe, B.F.; Schnitzer, M.J.; Anderson, D.J. Social behaviour shapes hypothalamic neural ensemble representations of conspecific sex. Nature 2017, 550, 388-392. [CrossRef]

62. Lee, H.; Kim, D.-W.; Remedios, R.; Anthony, T.E.; Chang, A.; Madisen, L.; Hongkui, Z.; Anderson, D.J. Scalable control of mounting and attack by Esr1+ neurons in the ventromedial hypothalamus. Nature 2014, 509, 627-632. [CrossRef] 
63. Costa, H.C.; Da-Silva, J.M.; Diniz, G.B.; Motta-Teixeira, L.C.; Da-Silva, R.J.; Battagello, D.S.; Sita, L.V.; de Moraes, M.C.; HortaJúnior, J.A.C.; Bittencourt, J.C. Characterisation and origins of melanin-concentrating hormone immunoreactive fibres of the posterior lobe of the pituitary and median eminence during lactation in the Long-Evans rat. J. Neuroendocrinol. 2019, 31, e12723. [CrossRef]

64. Lonstein, J.S.; Stern, J.M. Site and behavioral specificity of periaqueductal gray lesions on postpartum sexual, maternal, andaggressive behaviors in rats. Brain Res. 1998, 804, 21-35. [CrossRef]

65. Salzberg, H.C.; Lonstein, J.S.; Stern, J.M. GABA(A) receptor regulation of kyphotic nursing and female sexual behavior in thecaudal ventrolateral periaqueductal gray of postpartum rats. Neuroscience 2002, 114, 675-687. [CrossRef]

66. Rossier, D.; Franca, V.L.; Salemi, T.; Natale, S.; Gross, C.T. A neural circuit for competing approach and defense underlying prey capture. Proc. Natl. Acad. Sci. USA 2021, 118, e2013411118. [CrossRef]

67. Tsuneoka, Y.; Maruyama, T.; Yoshida, S.; Nishimori, K.; Kato, T.; Numan, M.; Kuroda, K.O. Functional, anatomical, and neurochemical differentiation of medial preoptic area subregions in relation to maternal behavior in the mouse. J. Comp. Neurol. 2013, 521, 1633-1663. [CrossRef]

68. Fang, Y.Y.; Yamaguchi, T.; Song, S.C.; Tritsch, N.X.; Lin, D.A. Hypothalamic Midbrain Pathway Essential for Driving Maternal Behaviors. Neuron 2018, 98, 192-207.e10. [CrossRef]

69. Wei, Y.-C.; Wang, S.-R.; Jiao, Z.-L.; Zhang, W.; Lin, J.-K.; Li, X.-Y.; Li, S.-S.; Zhang, X.; Xu, X.-H. Medial preoptic area in mice is capable of mediating sexually dimorphic behaviors regardless of gender. Nat. Commun. 2018, 18, 279. [CrossRef]

70. Numan, M. Medial preoptic area and maternal behavior in the female rat. J. Comp. Physiol. Psychol. 1974, 87, 746-759. [CrossRef]

71. Young, L.J.; Wang, Z. The neurobiology of pair bonding. Nat. Neurosci. 2004, 7, 1048-1054. [CrossRef]

72. Kelly, A.M.; Hiura, L.C.; Saunders, A.G.; Ophir, A.G. Oxytocin Neurons Exhibit Extensive Functional Plasticity Due To Offspring Age in Mothers and Fathers. Integr. Comp. Biol. 2017, 57, 603-618. [CrossRef]

73. Caitlin Post, C.; Leuner, B. The Maternal Reward System in Postpartum Depression. Arch. Womens Ment. Health 2019, 22, 417-429. [CrossRef] [PubMed]

74. Del Cid-Pellitero, E.; Jones, B.E. Immunohistochemical evidence for synaptic release of GABA from melanin-concentrating hormone containing varicosities in the locus coeruleus. Neuroscience 2012, 223, 269-276. [CrossRef] [PubMed]

75. Elias, C.F.; Lee, C.E.; Kelly, J.F.; Ahima, R.S.; Kuhar, M.; Saper, C.B.; Elmquist, J.K. Characterization of CART neurons in the rat and human hypothalamus. J. Comp. Neurol. 2001, 432, 1-19. [CrossRef] [PubMed]

76. Harthoorn, L.F.; Sañé, A.; Nethe, M.; Heerikhuize, J.J.V. Multi-transcriptional profiling of melanin-concentrating hormone and orexin-containing neurons. Cell Mol. Neurobiol. 2005, 25, 1209-1223. [CrossRef]

77. Abrahamson, E.E.; Leak, R.K.; Moore, R.Y. The suprachiasmatic nucleus projects to posterior hypothalamic arousal systems. Neuroreport 2001, 12, 435-440. [CrossRef]

78. Chee, M.J.S.; Arrigoni, E.; Maratos-Flier, E. Melanin-concentrating hormone neurons release glutamate for feedforward inhibition of the lateral septum. J. Neurosci. 2015, 35, 3644-3651. [CrossRef] [PubMed]

79. Jennings, J.H.; Sparta, D.R.; Stamatakis, A.M.; Ung, R.L.; Pleil, K.E.; Kash, T.L.; Stuber, G.D. Distinct extended amygdala circuits for divergent motivational states. Nature 2013, 496, 224-228. [CrossRef]

80. McHenry, J.A.; Otis, J.M.; Rossi, M.A.; Robinson, J.E.; Kosyk, O.; Miller, N.W.; McElligott, Z.A.; Budygin, E.A.; Rubinow, D.R.; Stuber, G.D. Hormonal gain control of a medial preoptic area social reward circuit. Nat. Neurosci. 2017, 20, 449-458. [CrossRef] [PubMed]

81. Gies, U.; Theodosis, D.T. Synaptic plasticity in the rat supraoptic nucleus during lactation involves GABA innervation and oxytocin neurons: A quantitative immunocytochemical analysis. J. Neurosci. 1994, 14 Pt 1, 2861-2869. [CrossRef]

82. Li, Y.; Gao, X.B.; Sakurai, T.; van den Pol, A.N. Hypocretin/orexin excites hypocretin neurons via a local glutamate neuron-a potential mechanism for orchestrating the hypothalamic arousal system. Neuron 2002, 36, 1169-1181. [CrossRef]

83. Marty, A.; Llano, I. Excitatory effects of GABA in established brain networks. Trends Neurosci. 2005, 28, 284-289. [CrossRef]

84. Kim, J.S.; Kim, W.B.; Kim, Y.-B.; Lee, Y.; Kim, Y.S.; Shen, F.-Y.; Lee, S.W.; Park, D.; Choi, H.-J.; Hur, J.; et al. Chronic hyperosmotic stress converts GABAergic inhibition into excitation in vasopressin and oxytocin neurons in the rat. J. Neurosci. 2011, 31, 13312-13322. [CrossRef]

85. Lee, S.W.; Kim, Y.B.; Kim, J.S.; Kim, W.B.; Kim, Y.S.; Han, H.C.; Colwell, C.S.; Cho, Y.W.; Kim, Y.I. GABAergic inhibition is weakened or converted into excitation in the oxytocin and vasopressin neurons of the lactating rat. Mol. Brain $2015,8,34$. [CrossRef]

86. Choi, K.; Lee, Y.; Lee, C.; Hong, S.; Lee, S.; Kang, S.J.; Shin, K.S. Optogenetic activation of septal GABAergic afferents entrains neuronal firing in the medial habenula. Sci. Rep. 2016, 6, 34800. [CrossRef]

87. Tirindelli, R.; Dibattista, M.; Pifferi, S.; Menini, A. From pheromones to behavior. Physiol. Rev. 2009, 89, 921-956. [CrossRef]

88. Brennan, P.A.; Zufall, F. Pheromonal communication in vertebrates. Nature 2006, 444, 308-315. [CrossRef]

89. Gutiérrez-Castellanos, N.; Martínez-Marcos, A.; Martínez-García, F.; Lanuza, E. Chemosensory function of the amygdala. Vitam. Horm. 2010, 83, 165-196.

90. Trainor, B.C.; Rowland, M.R.; Nelson, R.J. Photoperiod affects estrogen receptor alpha, estrogen receptor beta and aggressive behavior. Eur. J. Neurosci. 2007, 26, 207-218. [CrossRef]

91. Xu, X.; Coats, J.K.; Yang, C.F.; Wang, A.; Ahmed, O.M.; Alvarado, M.; Izumi, T.; Shah, N.M. Modular genetic control of sexually dimorphic behaviors. Cell 2012, 148, 596-607. [CrossRef] 
92. Trouillet, A.-C.; Keller, M.; Jan Weiss, J.; Leinders-Zufall, T.; Birnbaumer, L.; Frank Zufall, F.; Pablo Chamero, P. Central role of G

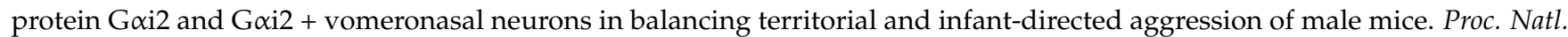
Acad. Sci. USA 2019, 116, 5135-5143. [CrossRef]

93. Chen, A.-X.; Yan, J.-J.; Zhang, W.; Wang, L.; Yu, Z.-X.; Ding, X.-J.; Wang, D.-Y.; Zhang, M.; Zhang, Y.-L.; Song, N.; et al. Specific Hypothalamic Neurons Required for Sensing Conspecific Male Cues Relevant to Inter-male Aggression. Neuron 2020, 108, 763-774.e6. [CrossRef] [PubMed]

94. Armstrong, S.D.; Robertson, D.H.L.; Cheetham, S.A.; Hurst, J.L.; Beynon, R.J. Structural and functional differences in isoforms of mouse major urinary proteins: A male-specific protein that preferentially binds a male pheromone. Biochem. J. 2005, 391 Pt 2, 343-350. [CrossRef]

95. Tolokh, I.I.; Fu, X.; Holy, T.E. Reliable sex and strain discrimination in the mouse vomeronasal organ and accessory olfactory bulb. J. Neurosci. 2013, 33, 13903-13913. [CrossRef]

96. Isoga, Y.; Si, S.; Pont-Lezica, L.; Tan, T.; Kapoor, V.; Murthy, V.N.; Dulac, C. Molecular organization of vomeronasal chemoreception. Nature 2011, 478, 241-245. [CrossRef] [PubMed]

97. Kimoto, H.; Sato, K.; Nodari, F.; Haga, S.; Holy, T.E.; Touhara, K. Sex- and strain-specific expression and vomeronasal activity of mouse ESP family peptides. Curr. Biol. 2007, 21, 1879-1884. [CrossRef] [PubMed]

98. Kumar, A.; Dudley, C.A.; Moss, R.L. Functional dichotomy within the vomeronasal system: Distinct zones of neuronal activity in the accessory olfactory bulb correlate with sex-specific behaviors. J. Neurosci. 1999, 19, RC32. [CrossRef]

99. Leypold, B.G.; Yu, C.R.; Leinders-Zufall, T.; Kim, M.M.; Zufall, F.; Axel, R. Altered sexual and social behaviors in trp2 mutant mice. Proc. Natl. Acad. Sci. USA 2002, 99, 6376-6381. [CrossRef] [PubMed]

100. Stowers, L.; Holy, T.E.; Meister, M.; Dulac, C.; Koentges, G. Loss of sex discrimination and male-male aggression in mice deficient for TRP2. Science 2002, 295, 1493-1500. [CrossRef]

101. Orikasa, C.; Kondo, Y.; Katsumata, H.; Terada, M.; Akimoto, T.; Sakuma, Y.; Minami, S. Vomeronasal signal deficiency enhances parental behavior in socially isolated male mice. Physiol. Behav. 2017, 168, 98-102. [CrossRef]

102. Stolzenberg, D.S.; Mayer, H.S. Experience-dependent mechanisms in the regulation of parental care. Front. Neuroendocrinol. 2019, 54, 100745. [CrossRef] [PubMed]

103. Fleming, A.S.; Vaccarino, F.; Luebke, C. Amygdaloid inhibition of maternal behavior in the nulliparous female rat. Physiol. Behav. 1980, 25, 731-743. [CrossRef]

104. Numan, M.; Numan, M.J.; English, J.B. Excitotoxic amino acid injections into the medial amygdala facilitate maternal behavior in virgin female rats. Horm. Behav. 1993, 27, 56-81. [CrossRef]

105. Sheehan, T.; Paul, M.; Amaral, E.; Numan, M.J.; Numan, M. Evidence that the medial amygdala projects to the anterior/ventromedial hypothalamic nuclei to inhibit maternal behavior in rats. Neuroscience 2001, 106, 341-356. [CrossRef]

106. Numan, M.; Young, L.J. Neural mechanisms of mother-infant bonding and pair bonding: Similarities, differences, and broader implications. Horm. Behav. 2016, 77, 98-112. [CrossRef] [PubMed]

107. Niu, J.G.; Yokota, S.; Tsumori, T.; Oka, T.; Yasui, Y. Projections from the anterior basomedial and anteriorcortical amygdaloid nuclei to melanin-concentrating hormone-containing neurons in the lateral hypothalamus of the rat. Brain Res. 2012, 1479, 31-43. [CrossRef]

108. De Jong, T.R.; Neumann, I.D. Oxytocin and Aggression. Curr. Top. Behav. Neurosci. 2018, 35, 175-192.

109. Pedersen, C.A.; Caldwell, J.D.; Walker, C.; Ayers, G.; Mason, G.A. Oxytocin activates the postpartum onset of rat maternal behavior in the ventral tegmental and medial preoptic areas. Behav. Neurosci. 1994, 108, 1163-1171. [CrossRef]

110. Zhang, G.-W.; Shen, L.; Tao, C.; Jung, A.-H.; Peng, B.; Li, Z.; Zhang, L.I.; Tao, H.W. Medial preoptic area antagonistically mediates stress-induced anxiety and parental behavior. Nat. Neurosci. 2021, 24, 516-528. [CrossRef]

111. Anpilov, S.; Shemesh, Y.; Eren, N.; Harony-Nicolas, H.; Benjamin, A.; Dine, J.; Oliveira, V.E.M.; Forkosh, O.; Karamihalev, S.; Hüttl, R.E.; et al. Wireless Optogenetic Stimulation of Oxytocin Neurons in a Semi-natural Setup Dynamically Elevates Both Pro-social and Agonistic Behaviors. Neuron 2020, 107, 644-655.e7. [CrossRef]

112. Shamay-Tsoory, S.G.; Abu-Akel, A. The Social Salience Hypothesis of Oxytocin. Biol. Psychiatry 2016, 79, 194-202. [CrossRef] [PubMed]

113. Steinman, M.Q.; Duque-Wilckens, N.; Trainor, B.C. Complementary Neural Circuits for Divergent Effects of Oxytocin: Social Approach Versus Social Anxiety. Biol. Psychiatry 2019, 85, 792-801. [CrossRef] [PubMed]

114. Ferretti, V.; Maltese, F.; Contarini, G.; Nigro, M.; Bonavia, A.; Huang, H.; Gigliucci, V.; Morelli, G.; Scheggia, D.; Managò, F.; et al. Oxytocin Signaling in the Central Amygdala Modulates Emotion Discrimination in Mice. Curr. Biol. 2019, 29, 1938-1953.e6. [CrossRef] [PubMed]

115. Caldji, C.; Diorio, J.; Meaney, M.J. Variations in maternal care in infancy regulate the development of stress reactivity. Biol. Psychiatry 2000, 48, 1164-1174. [CrossRef]

116. Francis, D.D.; Szegda, K.; Campbell, G.; Martin, W.D.; Insel, T.R. Epigenetic sources of behavioral differences in mice. Nat. Neurosci. 2003, 6, 445-446. [CrossRef] [PubMed] 